\title{
Putin og jeg - Russlands vei fra håp til håpløshet
}

\author{
Øystein Bogen \\ Oslo: Kagge forlag 2016 \\ 430 sider. ISBN 9788248918578
}

Omtalt av: Maren Garberg Bredesen [MA, juniorforsker, Norsk utenrikspolitisk institutt, mgb@nupi.no]

«Putin og jeg - Russlands vei fra håp til håpløshet» er TV2-journalist Øystein Bogens fortelling om Russlands utvikling under Vladimir Putins 17 år ved makten. Forfatterens diagnose på dagens situasjon er klar: Russland er på galoppfart tilbake til Sovjet-tiden, og en ny kald krig står for døra. Boken dreier seg nettopp om denne utviklingen, men også om Bogens personlige skuffelse over et land han har fulgt som journalist i over 20 år.

Forfatteren begynner sin personlige russlandshistorie som barn hjemme i Orkanger, der en overhengende redsel for en forestående atomvinter skapte en fryktbasert fascinasjon for Sovjetunionen. Senere, med en tenårings skuldertrekk og en skepsis for nerdekulturen blant sine medelever, meldte han seg opp ved Forsvarets russiskkurs. Det er i 1989, i ferd med å uteksamineres fra Forsvaret og på studiebesøk i DDR, at Bogens parallellhistorie om «Lille Volodja» - Vladimir Putin - som på dette tidspunktet var utstasjonert som KGB-agent i Dresden, tar fatt. Forfatterens historie om den unge Putin tegner et bilde av en temperamentsfull mann med et urokkelig lojalitetsbegrep. Ifølge Bogen var det spesielt årene som lojal og selvoppofrende rådgiver under St. Petersburgs borgermester Anatolij Sobtsjak som senere skulle skaffe Putin en jobb i presidentadministrasjonen. Han beskriver også en person som foretrakk et liv i skyggene, tilsynelatende uten større politiske ambisjoner. Som statsminister beskrives han like fullt som en mann med sterk reformvilje og som fikk ting gjort.

Bokas kapittel om Kursk-tragedien er, med god grunn, en brutal start på historien om Putins to første presidentperioder. Her møter vi Olga Kolesnikova, enken etter kapteinløytnant Dmitrij Kolesnikov. Olga ble i lang tid nektet å lese brevet som ektemannen skrev til henne gjennom de skjebnesvangre timene på Kursk fordi den russiske marineledelsen fryktet brevet kunne eksponere deres manglende redningsinnsats. Vi møter også andre pårørende, og deres historier er vevd sammen med detaljerte skildringer av hendelsesforløpet til en tragisk fortelling om det russiske forsvarets elendige tilstand og sjokkerende forsømmelse av Kursk-besetningens sikkerhet. 
Bogen bruker mye tid på Kursk-tragedien, som etter hans analyse utgjorde Putins første ydmykelse som president. Den andre ydmykelsen skulle bli skolemassakren i Beslan, hvor Putin igjen ble konfrontert med nasjonens mange kritiske spørsmål om hans kompetanse og motiver. Kursk-tragedien og Beslan ble etter Bogens mening skjebnesvangre leksjoner. Det er på denne tiden, rundt 2004, at han observerer en tiltagende paranoia hos Putin og et økende behov for detaljstyring. Det Putin opplever som Vestens onde hensikter er et internasjonalt stressmoment som sammenfaller med den innenrikspolitiske kritikken: NATOs utvidelse østover, fargerevolusjonene i Georgia og Ukraina og høylytt kritikk fra russiske avhoppere i Vesten. Et utdrag fra et finsk diplomatisk notat fra denne perioden, sitert i boken, konkluderer at: «Putin er i en sinnstilstand der han ikke kan bestemme seg for hva han skal giøre. [...] Han har ingen strategi eller visjon som hjelper han å komme videre». Gjennom de neste kapitlene beskrives det hvordan Putins løsning blir å stramme det autoritære grepet. Innskrenkningen av pressefriheten, rystende fortalt blant annet giennom drapene på Anna Politkovskaja og Aleksander Litvinenko; Georgiakrigen i 2008; den økende militariseringen av det russiske samfunnet; valgfusket i 2012 og drapet på Boris Nemtsov i 2015 representerer for Bogen, som for så mange andre russlandsobservatører, viktige og dystre milepæler i Russlands utvikling siden 2004.

Fortellingene, som ofte er basert på Bogens mange reportasjereiser, bærer biografiske preg og fremstår i så måte også som et slags personlig oppgjør med forfatterens tid i Russland. De er spekket med anekdoter, personlig fortalt med levende detaljføring. For eksempel er beretningene om hvordan Bogen flere ganger blir trakassert av FSB både spennende og skremmende, men også fortalt med et snev av sarkasme. Det er blant annet i Sotsji, under oppløpet til vinter-OL, at Bogen og kameramannen opplever den mest ubehagelige konfrontasjonen med den russiske sikkerhetstjenesten. På oppdrag for å lage reportasje om baksiden av det russiske OL-glansbildet blir de to anholdt ikke mindre enn syv ganger av russisk trafikkpoliti, satt $\mathrm{i}$ varetekt og utsatt for utallige trusler. Under slike omstendigheter er det imponerende hvordan begge likevel klarte å holde hodet kaldt og snedig dokumentere flere av hendelsene.

Annekteringen av Krim og borgerkrigen i Øst-Ukraina skildres gjennom forfatterens egne reiser under de skjebnesvangre dagene i mars 2014, fra Kiev til Simferopol og videre til Donbass. Møtet med Slava, den usjarmerende og homofobe opprørsgeneralen i Slavjansk, står i sterk kontrast til den fattede Dmiitrii, bataljonssjefen som i flere uker holdt stand mot «de små grønne menn» i den siste ukrainskkontrollerte kasernen på Krim. Vitneskildringene fra frontlinjen i Øst-Ukraina beskriver et meningsløst «helvete på jord». Med Sotsji friskt i minne er det i løpet av denne perioden at Bogens forhold til Russland blir nærmest fullstendig ødelagt.

Forfatteren skriver innledningsvis at for å fungere i Russland må en komme i takt med det russiske samfunnet og akseptere at russere er et folk som først og fremst tenker med hjertet og ikke fornuften. Som leser savner man likevel å høre mer om hans erfaringer i kontakt med gjennomsnittsrusseren og hva som har ført forfatteren til en slik relativ enkel konklusjon. Det refereres flere ganger til Putins popularitet (spesielt etter anneksjonen av Krim har oppslutningen ligget på rundt 80\%), 
men dette blir i stor grad avfeid som et resultat av en manipulativ politikk og frykt. Som Minda Holms fagartikkel i dette tidsskriftet tidligere har belyst så virker det noe enkelt å tilskrive Putins popularitet - og ikke minst den brede folkelige støtten til anneksjonen av Krim - utelukkende til russiske mediers løgner om hendelsesforløpet i forbindelse med konflikten i Ukraina. En mer nysgjerrig framstilling av Russlands historiske myter og kollektive identitet kunne bidratt til å nyansere det som tidvis kan leses som en stereotypifisering av russere som uopplyste, uinteresserte eller korrumpert av staten. Videre observeres den blomstrende nasjonalismen under Putin uten øvrige referanser til hverken drivkreftene bak eller forskjellene mellom Russlands flere - og ofte konkurrerende - nasjonalismer. En tydeligere stemme til Putins folkelige støttespillere, og en mer dynamisk drøftelse av stat, folk og identitet, hadde gitt analysen mer dybde. Boka svarer derfor ikke tilstrekkelig på flere sentrale «hvorfor?» om dagens Russland. Nå er kanskje ikke dette hovedintensjonen med boka heller, men satt i en større kontekst og som et bidrag i den polariserte debatten om forholdet mellom Russland og Vesten framstår fraværet av slike nyanser som uheldig, spesielt gitt den enorme kunnskapen om Russland som Bogen åpenbart sitter på.

For en leser med inngående kjennskap til Putin og hans politikk vil ikke «Putin og jeg - Russlands vei fra håp til håpløshet» nødvendigvis bidra med ny informasjon, men boka er like fullt tilgjengelig og begivenhetsrik lesning. Bogens fortellerstil giør fortellingene noe oppjaget, men gir den også et interessant og personlig korrespondent-preg. Som førstehåndsvitne gir han leserne uten tvil et spennende innblikk i mange av de begivenhetene som har formet Russland siden Putins entré. 